Acta Universitatis Wratislaviensis No 3836

Anglica Wratislaviensia LVI, Wrocław 2018

DOI: $10.19195 / 0301-7966.56 .7$

\title{
Jacek Olesiejko
}

ORCID: 0000-0002-7047-2498

Adama Mickiewicz University, Poznań

jolesiejko@wa.amu.edu.pl

\section{The Tension between Heroic Masculinity and the Christian Self in the Old English Andreas}

\begin{abstract}
The article's aim is to elucidate the religious transformations of the secular notions of identity and masculinity in Andreas. Andreas is a religious poem composed in Anglo-Saxon England around the ninth century. It is an adaptation of the Latin recension of the Acts of the Apostle Andrew, but the poet uses heroic diction borrowed from Old English secular poetry to rework the metaphor of miles Christi that is ubiquitous in Christian literature. The poet uses the military metaphor to inculcate the Christian notion of masculinity as the inversion of the secular perception of manliness. He draws upon a paradox, attested in the early Christian writings, that spiritual masculinity is true manliness, superior to military masculinity, and that it is expressed through patient suffering and the acknowledgment of defeat. The poem inverts the notions of war and victory to depict the physical defeat of the martyr as a spiritual victory over sin and the devil.
\end{abstract}

Keywords: Andreas, Old English poetry, gender studies, hagiography, Anglo-Saxon England

The Old English poem Andreas is an alliterative adaptation of an ancient Christian legend preserved in a number of Greek and Latin recensions. ${ }^{1}$ Christian in matter, it is told in language that resembles many verses of such Old English heroic poems like Beowulf. In Andreaas, Andreas' and Matthew's actions and characters are described with heroic formulas, as both are appellated with words resonant of secular and military connotations like "țegnas" "retainers' (Andreas: 1. 1026), "modigan" 'bold ones' (Andreas: 1. 1049), "wigend" 'warriors' (Andreas: 1. 1053), "hæleț

${ }^{1}$ In a critical introduction to his edition of the poem, Kenneth R. Brooks claims the ultimate source of the Old English poem is a Greek version of the legend of the adventures of Andrew and Matthew in the land of Anthropophagi which exists in nine redactions (Brooks 1961: xv). There is little evidence of Anglo-Saxons' knowing Greek, so the Andreas-poet have must been familiar with an unknown Latin redaction of the Greek version of the legend (Brook 1961: xv).

2 All quotations from Andreas are taken from Brooks 1961. All translations from Old English to Modern English are mine. 
hige rofe" 'courageous heroes' (Andreas: 1. 1054), or "cempan coste" "experienced warriors' (Andreas: 1. 1055). Derived from the vernacular and secular tradition though they are, in Old English versified saints' lives, these formulas are native counterpart to the Latin tradition of describing holy men and women as milites Christi. An issue that remains unstudied, regarding the poem, is the attitude towards the secular perception of masculinity that the Andreas-poet evokes and manipulates. Andreas has been extensively analysed for years ${ }^{3}$ and there have been some critical evaluation of the soldier of Christ theme in Andreas, even though none of these readings attempted to uncover the gender dynamics emergent in the poem. ${ }^{4}$ Most often critics view the poet's use of military language and Christian tradition as incongruous, ${ }^{5}$ while some critics doubt that the poem depicts Andreas as a miles Christi. For example, Thomas A. Shippey claims that "there is no hint that he [the poet] means the warfare of the spirit" and that "the heroic vocabulary has been used simply because it was ready to hand" (Shippey 1972: 117). In her broad study of the Soldier of Christ theme in Old English literature, Joyce Hill writes that the poet does refer to the tradition of spiritual warfare, but he only mechanically adapts it from the source.

The poet does not make reference to the wider perspective of the miles Christi tradition in which the hero's struggles may be seen as pattern and model of the Christian life. The saint's acts conform to those of the miles Christi only because the nature of his actions and experiences are predetermined in the given narrative, which the poet does not alter. If he was aware of the implications of this narrative, that spiritual warfare is one of obedience to God and calls for a different relationship between God and man than that between lord and retainer, he does not articulate it. (Hill 1981: 71-72)

3 The focus has recently been mainly on Mermedonia as a geographical and symbolic location. Alexandra Bolintineanu argues that Mermedonia is "a theological 'type' of the whole world, undergoing its own abbreviated history of salvation" (2009: 150). Shannon Godlove reads the Mermedonians as a 'type' of the Synagoga opposed to the Ecclesia (2009: 148). Lindy Brady claims that the Andreas-poet aligns "Mermedonia's geography with liminal spaces at the edges of the landscape of Anglo-Saxon England whose inhabitants were culturally charged as 'other' (2010: 670). Her point is the identification of this 'other' as Britons bordering with Anglo-Saxons (2010: 676). Robin Waugh reads Mermedonia as a textual city that represents the Old Testament (Waugh 2012: 260).

4 All major discussions of masculinity in Old English poetry disregard the significance of this trope in Andreas and the interaction of Christian and secular gender ideologies that function in $A n$ dreas. For example, David Clark does not include any discussion of the poem in Between Medieval Men: Male Friendship and Desire in Early English Literature (2009), a book that remains the only extensive treatment of gender and masculinity regarding Old English poetry.

5 In general, many critics of Old English versified saints' lives claimed that Cynewulf and other anonymous religious Old English poets evoked the heroic ethos only to devalue it and foster Christian ideas on the self. The locus classicus of such criticism is Claude Schneider's "Cynewulf's devaluation of heroic tradition in Juliana" (1978). Schneider's ideas were contested by Stephen Morrison (1979), who claims that the word cempa evokes not the secular heroic code but the Christian idea of miles Christi (1979: 82). He claims that "virtues of patience and passivity, the very means by which Juliana overcomes the devil, (521b, 543a) are fundamental attributes of the Miles Christi" (1979: 82). 
However, those readings of Andreas that explored its allegorical and typological structure led to a reappraisal of the view represented by Shippey and Hill. ${ }^{6}$ More recently Shannon Godlove eloquently analysed the miles Christi metaphor in the poem, claiming that the poet "points out a distinction between the apostles as spiritual soldiers and the Germanic ideal of the warrior band that supplies his descriptive vocabulary" (Godlove 2015: 182-183). She claims that the Andreas-poet juxtaposes the Germanic idea of comitatus with the Christian idea of divisio apostolorum and that the poems opening lines "play with the Anglo-Saxon ideal of the cohesion and unity of the aristocratic warrior band to explore the biblical paradox of the apostles' ability to persevere "with one mind" (Acts 1:14) and "in the doctrine of the apostles" (Acts 2: 42), despite their parting and dispersion across many lands" (Godlove 2015: 183).

Godlove suggests that the poet uses the heroic diction to portray the apostles according to Anglo-Saxon values. My point, however, is that the Andreas-poet advances the monastic perception of secular masculinity as not appropriate for the performance of holiness. I argue, against Hill's claim, that the poem does in fact articulate the difference between the heroic standards and the ideal of Christian life. I also argue that Andreas-poet evokes a paradox, popular in early Christian writings, that the true masculinity is found in apparent emasculation. The use of this trope helps to develop a model of masculinity that is different from secular idealisations of manliness and those deemed appropriate from Christian life. I would also like to claim that the Andreas-poet's reworking of the miles Christi motif depends on his reformulations of two themes that are central to the Old English secular poetic tradition, namely, the theme of treasure and that of exile. His purpose is to highlight the monastic call for solitude as the ideal state to generate the self that conforms to Christian and monastic ideals. Andreas belonged to a large tradition of texts that represent monastic life in terms of spiritual warfare and may have circulated among male religious audiences as a guidance to their spiritual life and an idealisation of monastic life as a spiritual, and yet masculine, endeavour.

${ }^{6}$ Constance Hieatt argues that "in the poem, there is a re-enactment or sub-fulfilment of Christ's Passion and Resurrection" (Hieatt 1976: 52). Hieatt suggests that "Andrew not only emulates Christ by suffering a parallel to His Passion - a requirement laid upon every Christian in some sense - but also endures a similar three-day sojourn in conditions which symbolise the grave and/or hell" (Hieatt 1976: 53). The idea that Andreas's near-martyrdom imitates Christ's passion is further developed by Frederick M. Biggs (1988: 415). 


\section{Spiritual warfare in the early Christian literary tradition}

Since the beginning of Christian literature, the tradition of describing holy men and women as warriors has been firmly established ${ }^{7}$ so the present discussion is limited to those formulations of the traditional image of the Christian soul as a soldier that are most relevant to the militant idea of the self found in Andreas. The metaphor of miles Christi was founded on verses from the Letter to Ephesians, 6.11-17.

induite vos arma Dei ut possitis stare adversus insidias diaboli quia non est nobis conluctatio adversus carnem et sanguinem sed adversus principes et potestates adversus mundi rectores tenebrarum harum contra spiritalia nequitiae in caelestibus propterea accipite armaturam Dei ut possitis resistere in die malo et omnibus perfectis stare state ergo succincti lumbos vestros in veritate et induti loricam iustitiae et calciati pedes in praeparatione evangelii pacis in omnibus sumentes scutum fidei in quo possitis omnia tela nequissimi ignea extinguere et galeam salutis adsumite et gladium Spiritus quod est verbum Dei

Put on you the armour of God, that you may be able to stand against the deceits of the devil for our wrestling is not against flesh and blood; but against principalities and powers, against the rulers of the world of this darkness, against the spirits of wickedness in the high places. Therefore, take unto you the armour of God, that you may be able to resist in the evil day and to stand in all things perfect. Stand therefore, having your loins girt about with truth and having on the breastplate of justice: And your feet shod with the preparation of the gospel of peace. In all things taking the shield of faith, wherewith you may be able to extinguish all the fiery darts of the most wicked one. And take unto you the helmet of salvation and the sword of the Spirit (which is the word of God). ${ }^{8}$

In early Christian writings, the military metaphor continued to be used and influenced the representations of martyrs as spiritual athletes. Tertullian (c. 155c. 240 A.D.) encouraged martyrs to view their deaths as battles against the devil: "let him find you armed and fortified with concord; for peace among you is battle with him" (Ad martyras: 694). ${ }^{9}$ For Tertullian, the martyrs physical defeat is a spiritual victory that testifies to their self-mastery in the face of fear and danger.

${ }^{7}$ An extensive discussion of spiritual warfare is offered by Katherine Allen Smith in War and the making of medieval monastic culture (2011). As for the origin of the concept, Mathew Kuefler claims that "the origins of this image are uncertain, though the phrase had been mentioned in earliest, Biblical Christianity, and there are Roman, Hellenistic, and Jewish uses of the metaphor of life as a battle" (2001: 112). Raymond Hobbs provides a thorough analysis of the references to warfare in the New Testament and demonstrates that it is used in three ways, referential, illustrative, and metaphorical (1995: 249-250). He finds the metaphorical references to be the most important and provides many antecedents for it from the Old Testament. Joyce Hill discusses the soldier of Christ motif in Anglo-Saxon literature in "The soldier of Christ in Old English prose and poetry" (1981).

${ }^{8}$ All quotations from the Bible are taken from Biblia Sacra Vulgata. 2007. (Edited by Robert Weber and Roger Gryson.) (The fifth edition.) Stuttgart: Deutsche Bibelgesellschaft.

9 The quotation from Tertullian's works are taken from Phillip Schaff (ed.). Latin Christianity: Its Founder, Tertullian. http://www.ccel.org/ccel/schaff/anf03.html (access: 8.11.2017). 
Yet the man who objected to the conflict, both fights with all his strength, and when victorious, he rejoices in the battle, because he reaps from it glory and spoil. It is our battle to be summoned to your tribunals that there, under fear of execution, we may battle for the truth. But the day is won when the object of the struggle is gained. This victory of ours gives us the glory of pleasing God, and the spoil of life eternal. But we are overcome. Yes, when we have obtained our wishes. Therefore we conquer in dying; we go forth victorious at the very time we are subdued. (Apology: chapt. 50, p. 81)

After the time of persecution ended with the edict of toleration of Gelarius in 311 A.D and the edict of Milan, issued by Constantine the Great in 313 A.D., the motif of the soldier of Christ gained much influence in Christian writings. Ambrose of Milan (340-397 A.D.) used the military metaphor to praise the continence of virgins, "who press into the houses of Christ, as soldiers of unwearied chastity" (Concerning Virgins: chapt. X, p. 823). ${ }^{11}$ In one of his epistles he extended the metaphor to all Christians, saying that "now everyone is a soldier of his true God" (Epistle XVII, 895). St Augustine of Hippo (354-430 A.D.) also drew upon this tradition in Confessions, looking for models of "the soldier of the heavenly host" in Scripture (Confessions: chapt. X.44, p. 206). ${ }^{12}$

The motif also pervaded the hagiographic tradition and The Life of St Anthony by Athanasius (d. 373), the earliest holy life, is replete with episodes featuring St Anthony at war with the devil and his temptation. He is called "the soldier of Christ" when confronted by the devil disguised as a black boy (Life of Anthony: 12). In the Life of Paul of Thebes, Anthony witnessed a Hippocentaur and "seized the shield of faith and the breastplate of hope, but this animal brought him the fruits of the date palm to eat on his journey, as pledges of peace" (Life of Paul of Thebes: 78). In The Life of St Martin of Tours by Sulplicius Severus (363-420 A.D.), Martin is conscripted and must fight against the barbarians in Gaul, but tells Caesar Julian that he refuses to fight for him: "Up until now I have fought for you; allow me now to fight for God. Let someone who intends to fight accept your bonus. I am the soldier of Christ, I am not allowed to fight" (Life of Martin of Tours: 138-139). The warfare that is waged with spiritual arms is superior to earthly warfare and is an expression of true, spiritual masculinity.

These and other Christian writings of the early, High and later Middle Ages may be interpreted as key to shaping Christian representations of masculinity. ${ }^{13}$

10 This fragment of Tertullian's Apology is quoted and discussed by Mathew Kuefler (2001: $112-113)$.

11 All quotations from Ambrose of Milan's works are taken from Schaff, Phillip (ed.). Ambrose. Selected Works and Letters. https://www.ccel.org/ccel/schaff/npnf210.html (access: 8.11.2017).

12 The quotations from Augustine of Hippo's Confessions are taken from Augustine. 1991. Confessions. (Translated by Henry Chadwick). Oxford: Oxford University Press.

${ }^{13}$ Liz Herbert McAvoy claims that early medieval anchorites explored the miles Christi metaphor to express and define their masculinity (McAvoy 2011: 11). Scott Wells demonstrates that the German King and Emperor Henry II, who promoted the Benedictine renewal of monasteries under royal jurisdiction, used the miles Christi metaphor to portray "the ideal cloistered life in emphatically bellicose terms" (Wells 2010: 57-58). Katherine Allen Smith defines two reasons for the popularity 
According to Matthew Kuefler, Tertullian used the military metaphor extensively to defend Christians who refused to bear arms and defend themselves militarily against the accusations of cowardice (Kuefler 2001: 112).

The paradox to which Tertullian alluded, that in the martyrs' seeming defeat they conquer, is simply the first instance of what would become a general theme in Latin Christian writings about masculinity: that true manliness is found in apparent unmanliness. In refusing to be soldiers, Tertullian argued, Christians were in fact showing themselves to be more militaristic and manlier than their pagan counterparts. (Kuefler 2001: 113)

As Kuefler demonstrates, the early Christian writers "made a frequent reference to the paradox of the Christian reversal of symbols, in which weakness of strength and defeat was victory, to create a manifestor for a new Christian masculinity" (Kuefler 2001: 111). Central to the Christian model of manliness is the difference between the Christian and the secular attitudes towards victory; "while a secular soldier who did not win the battles in which they fought was no good soldier, the Christian soldier won the battle by remaining passive in the face of violence and gained victory in the very fact of being defeated" (Kuefler 2001: 115).

A similar argument is drawn by Edward Christie in his reading of Ćlfric of Eynsham's royal lives of St Edmund and St Oswald, Anglo-Saxon kings, who were recognised as saints on account of their holy lives and heroic martyrdom on the battlefield. The Northumbrian king Oswald was defeated by the Mercian king Penda at Maserfield in 642 A.D. King Edmund of East Anglia was killed by Viking invaders in 870 A.D. Although both kings were secular warriors who fought with physical, not spiritual, weapons, their deaths are nonetheless narrated as martyrdoms and, like martyrs' deaths, their violent ends are represented as a reversal of symbols associated with the military activity of soldiers. As Edward Christie claims, Ćlfric's reworking of their legends demonstrates that by choosing to die rather than fight, these two kings defy the heroic notion of submission and surrender as unheroic and emasculating (Christie 2004: 147). "The martyr king," Christie argues, "in fact sacrifices the very capacity to subject others to his will that is a prime factor in heroic masculinity and, instead, subjects himself entirely to the will of God" (Christie 2004: 147).

of the metaphor in the twelfth century; "Most men who entered monastic communities came from the ranks of families of bellatores, the martial elite then coalescing into a self-consciously defined noble class. For men from such backgrounds, especially the growing number whose conversions to the religious life occurred in adulthood, speaking the language of war may have allowed them to identify with masculine ideals familiar to them from their earlier lives. But martial rhetoric also appealed strongly to monastic authors, such as Peter Damian, who came from humble backgrounds, as well as those who, like Orderic Vitalis, spent their lives from childhood onward in the cloister" (2010: 87). Smith goes on to say that "rather than competing with knightly masculinity based on aggression and martial skill, clerics used familiar masculine attributes to formulate a distinct concept of masculinity, one which celebrated an ideal of a powerful, yet celibate, male who successfully 'fought' and 'conquered' his flesh with God's help" (2010: 87). 
As I will show, similar conclusions can be drawn regarding the Old English poem Andreas. The poet presents a similar paradox of apparent unmanliness as the supreme expression of spiritual masculinity. The heroic discourse is evoked to show the contrast between secular and religious perceptions of masculinity. The poet represents Andreas's faith and his near-martyrdom as heroism that is available to all believers, showing Andreas to be reluctant to follow God's commandments and fallible, and yet capable of achieving spiritual victory over the devil. The poet deliberately presents the saint as lacking some of the heroic qualities expected of the characters from secular poetry to articulate his Christian and monastic definition of masculinity.

\section{Andreas and Old English heroic tradition}

To analyse the religious notion of masculinity in Andreas, the present article situates the poem in the larger context of Old English heroic poetry to trace the tension between the heroic identity, present in such secular poems as Beowulf and the Old English elegy Wanderer, and the Christian tradition, which insists on the paradox that the perceived unmanliness is the ultimate source of a monk's spiritual masculinity. In the poem, this tradition is evoked to construct an alternative notion of the self that is conceived as an inversion of the homosocial bonds structuring society in heroic verse and it is pertinent to pay attention the possible parallels between Andreas, Beowulf and other poems, which have been attested by many readers of the poem. ${ }^{14}$ Although in contemporary scholarship the poems are not considered to be directly related to one another, the Andreas-poet seems to make a conscious use of the heroic tradition in his religious poem, especially the theme of treasure and the theme of exile.

The present article will use Stephen Baker's idea of the exchange of honour and Jos Baselsmans's concepts of 'worth' and 'image' as the external constituents of heroic identity in secular verse. In heroic poetry, material culture is an expression of the bond between the individual and society. Masculinity in the heroic world is attested by the performance of heroic deeds as well as by the participation

14 The similarity between Andreas and Beowulf is best accounted for by the formulaic nature of Old English verse and the same tradition from which both poets drew fixed expressions. This similarity, however, has been approached differently by various scholars. David Hamilton claims that the poet consciously draws upon Beowulf and "works hard at putting the materials of Beowulf to new uses" (Hamilton 1975: 84). He discovers "a system of compatibility between them [Andreas and Beowulf (Hamilton 1975: 85) and provides a number of instances of verses that appear in similar context in both poems. Kenneth R. Brooks lists narrative and linguistic parallels between Andreas and Beowulf in his critical introduction to the poem (Brooks 1961: xxiii). He claims that "certain passages in Andreas $[\ldots]$ show such a close resemblance to others in Beowulf that the theory of conscious imitation becomes hard to deny" (1961: xxiv). Edward B. Irving (1983: 215) and Leornard J. Peters (1951: 884), however, both strongly object to the possibility of Beowulf's influence on Andreas. 
in processes of economic exchange. In heroic society the norms and practices of gift-giving and exchange position individuals, as agents of exchange, in an intricate web of obligations. The hero participates in what Stephen Baker calls the economy of the exchange of honour, namely, a system of exchange in which "treasure and honour, indissolubly bonded, are traded up and down the social hierarchy in such a way that the participants gain (and occasionally lose) honour with each transaction" (Baker 2013: 37). Treasure and military accoutrements are adjunct to the masculine body in Beowulf. They articulate the individual's status, his kinship relationships and sworn obligations, as well as his belonging to society. Beowulf's thanes who accompany him on his last expedition to fight the dragon are reminded by Wiglaf that the weapons they are carrying are material signs of their sworn loyalty to the king.

Also, one's identification as a man is also linked to what Jos Baselmans defines as 'worth' and 'image' in his study of Beowulf. Using Ernst Leise's concept of Ehrensold-Ordnung, Jos Baselmans observes that "the significance of wealth in Germanic society ... lies not in its aesthetic enjoyment or the life comforts that it yields — valuable gifts should be, after all, reciprocated and passed on - but rather in shaping of the personal worth of its giver or recipient" (Baselmans 1999: 162). Baselmans's claim is that apart from the inner constituents of personhood such as mind and soul, there is an attribute that he calls 'image' or 'worth', the essential and defining attribute of the hero the heroic language of Beowulf (Baselmans 1999: 157). 'Worth', Baselmans claims, is an external quality, ostentatiously represented by war gear and valuables that were passed on to the individual as gifts from his father or lord. They not only raise the hero's esteem but also are material signs of his bonds with the lord and his tribal ancestry (Baselmans 1999: 159).

If the hero's body is evoked as a text, its marks of masculinity, constituted by signs of wealth and war accoutrements that constitute an inscription of the individual's kinship relationships as well as his tribal history onto his body. Similarly, Christianity represents the saint's body as a text, an embodied representation of the Word. In one of the most interesting readings of the poem, Christophe Fee argues that Andreas's body "is rewritten through his passion to become 'the Word'; to illustrate that the torturer's scourge is the pen which does this writing upon the tablet of Andreas's flesh; and to call attention to the act of authorship of the poet, which, inverting the torturer's role, uses a pen to enact Andreas's passion upon the parchment, the flesh of a 'lamb"' (Fee 1995: 56). Robin Waugh develops this point by reading Matthew and Andreas as a personification of the bible and linking the cannibalism of the Mermedonians to a textual blindness: the cannibals "threaten not only to consume bodies of God's messengers but also to eat the message itself; they threaten not only to destroy God's work and plans but also to eat words that represent God's breath and His gift of life" (Fee 1995: 260). I argue that Andreas-poet uses the secular epistemology that reads bodies in terms of symbols that represent masculinity and community. These two conflicting epistemologies sharpen the difference between religious and secular perceptions of masculinity. 
The poem reveals a conception of the body as a text on which Christian and secular cultures contend with one another to inscribe cultural meanings. In the poem, the secular epistemology of the body, which conceives of treasure and gifts as marks of masculinity is contested as spiritual blindness, a refusal to recognise the imago Dei behind the saints' spiritual deeds. In the moment of martyrdom, the body of the saint is viewed as an image of Christ's body. The Mermedonians who assail Andreas are compared to the Jews who denied that Jesus Christ was God. On account of their treatment of Andreas, the Mermedonians' spiritual blindness is identified with the blindness of Synagoga.

\section{Spiritual masculinity in Andreas}

Since the poem is not well-known, a detailed summary will be useful to explore the significance of the relationship between the poem's content and diction. Apostle Matthew arrives in the island of Mermedonia, inhabited by anthropophagi feeding upon newcomers' flesh and blood, since bread and water are inaccessible to them. They capture Matthew, blind and imprison him. Matthew, as all other arrivals, is going to live thirty days before being eaten. God promises to release him and orders Apostle Andrew, who is on a proselytizing mission in Achaia, to enfranchise Matthew. Andrew arrives at a beach on the Greek coast and finds a helmsman, who reluctantly accepts Andrew and his disciples on board. The helmsman interrogates Andrew regarding the nature of his faith. The apostle tells of him of the Jews, who did not want to acknowledge Christ's divinity despite the numerous miracles that Christ wrought in their presence, including the monument of an angel addressing the Jews and the three patriarchs of the Old Testament, who rose from their graves to announce that Christ is God. When Andrew and his men wake up, safe on the island of Mermedonia next day, the apostle realises the helmsman was Christ in disguise. Christ appears as a child and says to Andreas that he is to arrive in the city of Mermedonia, release Matthew and suffer torment at the hands of the Mermedonia. Andrew is made invisible and once he releases Matthew, the Mermedonians are so anxious to nourish themselves with food that they cast lots to choose a victim amongst themselves. An old man is chosen, but offers his own son as food instead of himself. The young man is about to be killed and consumed when a devil appears and reveals Andrew's presence. The apostle is immediately caught and imprisoned. He suffers three days of torture. After the round of the three days is complete, he prays to God and a flood of water rushes from under the pillars of the prison. The water, typologically evoking the sacrament of baptism, drowns the Mermedonians. They are then resurrected, apart from the most evil ones. They convert, elect a bishop and build a church. Andrew leaves the Christianised land.

The poem uses martial language to describe the homosocial bond between Matthew and Andrew approvingly. The very introduction depicts the twelve 
apostles' dispersion in disseminating the faith among nations in terms of a joint military endeavour

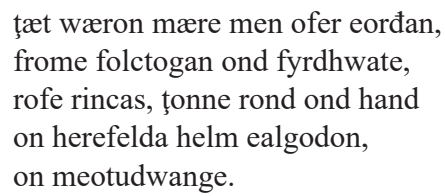

They were great men on earth, bold and warlike leaders, brave warriors. On the battlefield they raised arms and shields to protect their helmets, on the plain of doom. (Andreas: 11. 7-11)

The Andreas-poet borrows formulas from the heroic tradition that are conducive to articulating secular parameters of masculinity. In Beowulf, twelve Geats who carry Grendel's head to Heorot are called "frome fyrdhwate" 'bold and warlike' (Beowulf: 1. 1641), ${ }^{15}$ a collocation paralleled in line 8 of Andreas quoted above. In secular poetry, these parameters of articulating heroic masculinity are aligned with the values of the elite class of Anglo-Saxon warrior aristocracy, the primary audience of Anglo-Saxon secular verse.

The language of power and violence that describes Matthew's mission refers to spiritual warfare and the "rond" "shield' of line 9 is likely to evoke the shield of faith from Ephesians 6.11-17. Once he arrives in Mermedonia, however, the saint is greeted with physical violence and he finds himself in the emasculating position of powerlessness.
pa wæs Matheus to ţære mæran byrig cumen in ţa ceastre. ţær wæs cirm micel geond Mermedonia, manfulra hlođ, fordenera gedræg, syțţan deofles pegnas geascodon æđelinges siđ.
Eodon him pa togenes, garum gehyrsted, lungre under linde, (nalas late wæron), eorre æscberend, to ţam orlege.

Then Matthew came to that great city. There was a great turmoil over Mermedonia, as the troop of the evil, a tumult of the damned, the devil's thanes, inquired into the nature of the prince's exploit. They advanced against him, equipped with javelins and shields (they were not slack). The spear-bearing people were coming to battle (Andreas: 11. 41-47)

Matthew's powerlessness is especially glaring in the context of the strong cohesive group of the Mermedonians. His violated body and physical loss of vision bring attention to his corporeal fragility. His weakness, however, is a precondition for martyrdom, which is a reiteration of Christ's passion in the hagiographic tradition. This episode, I argue, introduces the perception of passive suffering involved

15 All quotations from Beowulf are taken from R.D. Fulk, Robert E. Bjork \& John D. Niles (eds.). 2008. Klaeber's Beowulf. (The fourth edition.) Toronto: University of Toronto Press. 
in martyrdom as the fulfilment of the apostles' spiritual masculinity, a perception that defies the secular notion of the submission to suffering as emasculating.

There is another element that the poet borrows from the heroic ideal. When God is consoling Matthew, promising to release him from imprisonment, he is mindful of the "sybbe" 'peace, kinship' (Andreas: 98) between Himself and Matthew. In heroic poetry, $s y b b$ (or sibb) refers to the peace that exists between relatives or tribes. The Beowulf-poet speaks of the members of the Danish royal family as being "hiera sib ætgædere æghwylc ođrum trywe" "mindful of their kinship to each other' (Beowulf: 11. 1165-1166). As for religious poetry, an example can be adduced from Juliana, where the saint uses the word "sybb" 'peace' (Juliana: 1. 652) to describe her bond with Christ. Edward B. Irving observes that God's address to Matthew highlights "the intimacy of the lord's speech to his faithful soldier" (Irving 1983: 218). The bond between God and Matthew is an example of the reversal of symbols that Mathew Kuefler locates in a number of early Christian writings (Kuefler 2001: 211-213). Matthew's defeat testifies to his internal spiritual self-mastery as well as his unswerving obedience to the spiritual authority of God.

In the episode that follows the description of Matthew's imprisonment, Andreas arrives at a Greek beach to seek transport to Mermedonia and meets a helmsman who is just about to leave for the land of the cannibals. The humour and irony in Andreas are at its highest when the helmsman, Christ himself in disguise, regards Andreas and his life of religious renunciation from the secular perspective. He is reluctant to accept Andreas on board on account of his glaring destitution, the constitutive mark of the saint's commitment to otherworldly values. The poem provides a perspective from which Andreas is to be viewed as the abject, not conforming to the secular parameters of masculinity.

Næbbe ic fæted gold ne feohgestreon,

welan ne wiste ne wira gespann,

landes ne locenra beaga, ţæt ic ţe mæge lust ahwettan,

willan in worulde, swa đu worde becwist.

I do not have either decorated gold, treasure, or any possessions, either food or fine bracelets, either tracts of land or interlocked rings. I cannot satisfy your desire for the worldly joy, as you are requesting with your words. (Andreas: 11. 301-304)

Andreas regrets to be unable to pay in "fæted gold" 'decorated gold' or "feohgestreon" "treasure'; such items occur in the context of treasure-giving in Beowulf. For instance, the Danes are appeased with gifts of "fætan goldes" 'decorated gold' (Beowulf: 1. 1093) by the Frisians in the song of Hilderburh. At Hygelac's court in Geatland, Beowulf boasts of "fæten golde" 'decorated gold' (Beowulf: 1. 2103) that Hrothgar showered on him. In heroic poetry, sworn ties are confirmed with gifts.

Being a religious man, Andreas does not conform to the identity that is, apparently, articulated by the helmsman. He maintains the difference between the helmsman and himself, defining himself as a man who follows an alternative pattern of 
obligation and endorses obedience to an otherworldly authority. Retorting to the helmsman's insult, he speaks of Christ as his lord and evokes his command to live a life of self-abnegating renunciation.

Farađ nu geond ealle eorđan sceatas emne swa wide swa wæter bebugeđ, ođđe stedewangas stræte gelicgaţ. Bodiađ æfter burgum beorhtne geleafan ofer foldan fæđm. Ic eow freođo healde. Ne đurfan ge on ţa fore frætwe lædan, gold ne seolfor. Ic eow goda gehwæs on eowerne agenne dom est ahwette

Go to all regions of the earth, as far as the water circumscribes it or roads lie upon the plains. Preach the glorious faith in cities across the world. I guard you with peace. You do not need take treasures, either gold or silver. I will supply you with grace according to your need. (Andreas: 11. 332-339)

Andreas exposes the alterity of Christian identity. Vita activa and contemplativa that lie at the foundation of monastic life place the individual essentially outside the parameters of secular identity. The individualism and abnegation that religious men value dissolves the body politic of comitatus, as their performance of gendered identity does not perpetuate the exchange of honour that engenders masculine bonds in the secular society. Such religious poems as Andreas, ${ }^{16}$ therefore, make normative representations of men that would have come across as queer in secular culture.

The idea of Christian identity in Andreas is defined against the ideal of masculinity perpetuated in secular verse in yet another dimension. Apart from the theme of gifts and treasure, the poet explores the theme of exile in Andreas to develop a model for the religious performance of masculinity. In her recent reading of Andreas, Alexandra Bolintineanu remarks that "Andreas is repeatedly a 'figure' isolated from other human beings' in his otherworldly place. He goes into the Mermedonian prison unaccompanied by any other people; his only helper is the Holy Spirit, who opens the prison door. Later, he dismisses his disciples and the rescued prisoner, and endures his capture and martyrdom alone" (Bolintineanu 2009: 157). Bolintineanu suggests that Mermedonia is associated with exilic landscape resembling the landscape of The Wanderer and Wife's Lament, but argues that in contrast to these elegiac landscapes, Andreas does not represent an internal conflict, but the external conflict "between the saint and the local population" (Bolintineanu 2009: 157). I would say that the poet indeed invokes the theme of exile, but his aim is to juxtapose the secular and the spiritual ideals of performing masculinity.

16 Speaking of another Old English hagiographic poem, Guthlac A, Jeffrey Cohen claims that "the first twenty-nine lines suggest that Guthlac's battle against the fantastic foes will nonetheless set him against the Ingelds and Beowulfs of heroic tradition, against those exemplary bodies whose hold over the contemporary performance of masculinity that Guthlac story challenges" (Cohen 2003: 123). 
The larger context of Old English religious and secular verse is useful for elucidating the Andreas-poet's use of the traditional theme of exile, as he gathers a host of formulas that derive from the secular formulaic expression of the theme of exile, so ubiquitous in Old English verse and shared by such poems as The Wanderer or The Seafarer. The theme was the subject of Stanley B. Greenfield's astute article "The formulaic expression of the theme of exile in Anglo-Saxon poetry" (1953). The poem's reference to Andreas as "anhaga" 'exile' (Andreas, 11351) evokes the "anhaga" from The Wanderer's opening lines (The Wanderer: 1. 1). ${ }^{17}$ Key to the image of exile, according to Greenfield, is the exile's condition of deprivation. Grendel is thus "dreame bidæled", while Satan is "duguthum bidćled" 'deprived of his powers' (Christ and Satan: 1. 121). ${ }^{18}$ Greenfield adduces numerous other examples to identify a formula "consisting of the instrumental or genitive, singular or plural, of the "property' removed together with the past participle of a verb of deprivation" (Greenfield 1989: 127). The traditional repertoire of formulas used across secular and religious verse offers a variety of phrases that emphasise an exile's destitution. In Anglo-Saxon poetry, a typical anhaga is not only freondleas, but also deprived of treasure.

While secular masculinity is defined by an individual's strong bond with comitatus, religious practices require solitude. Religious notions of identity that are articulated in Anglo-Saxon religious verse bring in the secular notion of the abject; a religious individual is cast as an exile, which may be associated with the Augustinian notion of Christians as exiles. In secular poetry, the idea of "anhaga" 'solitary one' displays the negative connotations of unhappiness and suffering. In religious poetry, however, holiness is predicated upon the union with God that is only achieved in solitude. Such a solitude presupposes a queered identity that is dislocated from the homosocial bonding common in secular society. Saint Guthlac of Crowland, in the Old English Guthlac B, is "anhoga" (Guthlac B: 1. 997). In Guthlac A, the saint draws a parallel between his living "an" 'alone' and God's oneness (Guthlac A: 1. 244). ${ }^{19}$ The holy men's disregard for homosocial bonds is thus one of the conditions of their conversion from secular society.

The devils who attack and torment Andreas repudiate him as "anhagan" "solitary one' (Andreas: 1. 1351). As Andreas recalls Christ's cry from the Cross "hwæt forlætest ţu me?" 'why do you forsake me?' (Andreas: 1. 1413) Christ's consoles Andreas, saying that the saint should not weep over his exile, since Christ extends his "friđe" 'protection' (Andreas: 1. 1432) to him

Ne wep ţone wræcsiđ, wine leofesta,

nis pe to frecne. Ic pe friđe healde,

minre mundbyrde mægene besette.

Me is miht ofer eall

17 All quotations from The Wanderer are taken from Anne L.Klinck (1992). The Old English elegies: A critical edition and genre study. Montreal: McGill-Queen's University Press.

18 All quotations from Christ and Satan are taken from George Phillip Krapp. 1931, ed. The Junius Manuscript. New York: Columbia University Press.

${ }^{19}$ All quotations from Guthlac A and Guthlac B are taken from Jane Roberts, 1979. 
Do not weep over your exile, the dearest of friends, as it is not fearsome to you. I will give you my peace and shelter you with my might and protection. My might prevails over everything. (Andreas: 11. 1431-1434)

In the secular world, the life of exile displaces an individual from "friđe", peace and protection guaranteed through a warrior's closeness to his lord. However, conversion from the secular world and from the values that define secular men is the condition for achieving "friđe" that brings cohesion to a religious community as well as the individual's relationship with God.

The life of exile is bemoaned as a condition of powerlessness in secular culture; in Christianity it is a prerequisite of sanctity. Miles Christi is defined through abjection from secular forms of representations of the self and the society. However, in Old English religious verse, the motif of deprivation articulates abnegation that determines one's identity as a Christian converted from the secular world. Andreas's conversion from the world is made manifest by the emphasis laid on his displacement from secular notions of the economy of honour, which is a testimony to Andreas's life of holy renunciation. Andreas is called "mađđum bedæled" 'deprived of treasure' (Andreas: 1. 309), when facing the helmsman at the Achaean shore. Solitude is valued in Anglo-Saxon religious literature as a manifestation of the conversion from the world and its materialistic values.

Andreas demonstrates that the performance of spiritual deeds may only be achieved in exile. Andreas unfolds an ongoing difference between Christ and his disciples' community and the communities represented by their enemies. Authority and power in Old English verse are substantiated architecturally, with the hall as the symbolic site of exercising authority. When Christ finds himself in Jerusalem preaching to a crowd, he is called "burgweard" 'the defender of the city' (Andreas: 1. 600).

Oft gesamnodon side herigeas,

folc unmæte, to frean dome,

pær hie hyrcnodon haliges lare.

đonne eft gewat æđelinga helm,

beorht blædgifa, in bold ođer,

đær him togenes, god herigende,

to đam međelstede manige comon,

snottre selerædend. Symble gefegon,

beornas bliđheorte, burhweardes cyme.

They often gathered together, the immense multitude, to hear the Lord speak. There they listened to the holy man's teaching. When the protector of princes again departed to another hall, the bright giver of happiness. The wise hall-dwellers came to the meeting-place to meet him and listen to God. The happy warriors enjoyed the feast and the coming of the defender of the city. (Andreas: 11. 652-660)

The Jews, who force Christ out of the temple, undermine Christ's position as "burgweard" 'the defender of the city' (Andreas: 1. 660). Their derisive attack 
on Christ conveys their idea of themselves as a cohesive group of city dwellers, while Christ and the body of his disciples are depicted as outcasts. The Jews consider them to be outsiders and claim that Christ and his companions "wadad wid-lastas" 'follow in the footsteps of exiles' (Andreas: 1. 677), perceiving them as exiles living a suspicious life of independence from communal bonds. The apostles are dismissed as those who "ell-țeodiges nu butan leod-rihte larum hyrađ" "hear the teachings of a foreign man who does not have any legal rights' (Andreas: 11. 678679). The apostles are perceived as lordless; when they declare that Christ is their prince, the Jews dismiss Christ as not possessing wealth ("eadiges orhlytte æđeling cyđađ" 'you call him a prince, although he is devoid of goods', Andreas 1. 680). The paradox of Christ being both burgweard and an exile encapsulates the Augustinian idea that the Christians, the dwellers of the symbolic Civitas Dei, live on earth in a state of exile from heaven. In The City of God Saint Augustine conceptualises human life as "a life of captivity in this earthly city as in a foreign land" (XIX: 17, p. 877 $)^{20}$ and says that "God's city lives in this world's city, as far as its human element is concerned; but it lives there as an alien sojourner" (XVIII: 1, p. 761). The displacement that Christ and his followers are subjected to is a figuration of the Triumphant Church that is architecturally imagined as a hall. Andreas's body enacts its own displacement from the world in a way that is profoundly suggestive of the Augustinian notion of citizens of the City of God as exiles. Poems like Andreas construct a notion of selfhood that is contingent on the ongoing differance between the secular and Christian notions of heroism and selfhood.

The idea of martyrdom as heroism is used to convey the Christian understanding of the self. The poem, I would argue, articulates the paradox that Christian men must defy secular expectations of masculinity to prove their spiritual masculinity in the eyes of other Christians. As Tertullian remarks in Apology, regarding the sufferings and deaths of martyrs in Roman circuses, "this victory of ours gives us the glory of pleasing God, and the spoil of life eternal. But we are overcome. Yes, when we have obtained our wishes. Therefore we conquer in dying; we go forth victorious at the very time we are subdued" (Apology: chapt. 50, p. 81). Andreas, like Christ, is to become the object of scorn, his physical disempowerment being a spectacle of emasculation. When Christ addresses Andrew to prepare the saint for the confrontation with the Mermedonians, he tells him that the defeat he is going to suffer signifies a spiritual victory and that Andreas passion will be a figure of Christ's passion. ${ }^{21}$

20 All quotations from St Augustine's City of God are taken from Augustine. 2003. The city of God. (Translated by Henry Bettenson) London: Penguin Books.

21 Frederick M. Biggs demonstrates that the Andreas-poet follows the patristic tradition in representing "Andreas's suffering as an imitation of Christ's passion" (1988: 415). His argument is that the Andreas-poet expands on his Latin source to sharpen the idea of Andreas as the type of Christ and his near-martyrdom as the type of Christ's passion (1988: 426). 
$\mathrm{Nu}$ đu, Andreas, scealt edre geneđan in gramra gripe. Is ţe guđ weotod, heardum heoruswengum scel ţin hra dæled wundum weorđan, wættre geliccost faran flode blod. Hie ţin feorh ne magon deađe gedælan, ţeh đu drype đolie, synnigra slege. đu ţæt sar aber; ne læt țe ahweorfan hæđenra ţrym, grim gargewinn, ţæt đu gode swice, dryhtne ţinum. Wes a domes georn; læt đe on gemyndum hu ţæt manegum wearđ fira gefrege geond feala landa, ţæt me bysmredon bennum fæstne weras wansælige. Wordum tyrgdon, slogon ond swungon, synnige ne mihton ţurh sarcwide sođ gecyđan.

Andreas! Now you will quickly venture into the grip of the fierce ones. War is appointed to you and your body will be dismembered with hard sword-strokes. Blood will flow from your wounds as water flows in a stream. They will not be able to deprive you of your life, even though you will suffer blows at the hands of the sinful. You must endure the affliction. Do not let the host of heathens, their fierce strife of spears, turn you away from your lord and abandon him. Be always eager for victory. Remember how well-known it is to people across many lands that they mocked me when I was bound with strong fetters. The wretched insulted me with words, they beat and scourged me. The sinful ones with their bitter retort could not see the truth. (Andreas: 11. 950-965)

The plot of the poem unfolds to inculcate the submission to passive suffering as the true ideal of masculinity. The parallel between Andreas's and Christ's bodies underlines Andreas's passivity. ${ }^{22}$ His body is subjected to the physical torment that earns disgrace, the Mermedonians's "sarcwide" 'reproach' (Andreas: 1. 965). In heroic society, the exposition to shame is perceived as a particularly humiliating and emasculating experience. As the victim of torment exiled from society, Andreas is not able to articulate 'worth', which is constitutive of a heroic identity. The mockery to which Andreas is going to be exposed during his passion is viewed as shameful. And yet, Andreas's emasculation is essential for the saint's identification with Christ. Christ describes his own passion as an equally humiliating experience. Humiliation and submission are necessary for the formation of the monastic self.

22 In his study of Ælfric's Old English Life of Edmund, written at the beginning of the eleventh century, Edward Christie claims that "The feminising implications of the later, monastic desire for union with Christ are prefigured in the desire of the Christian, Anglo-Saxon warrior, whose emulation of Christ rests in remaining passive where the masculine role of 'exploit' had defined the pagan warrior" (Christie 2004: 152). "The potential for the emulation of Christ to undo their heroic identity", which Christie studies in the context of Life of St Edmund (2004: 144), may also be identified in Andreas. 
This paradoxical perception of masculinity is maintained by a series of parodies and inversions that cast the Mermedonians as an anti-comitatus. While Andreas is learning to achieve the true mastery of the self, the Mermedonians are represented as a parody of heroic society. Firstly, Andreas's spiritual deeds are enacted as acts of charity on which the homosocial bonds between the disciples are predicated. As Andreas rushes into prison to free Matthew, the poet goes on to describe in detail both saints' gestures that exude affection.

Geseh ţa under swegle swæsne geferan,

halig haligne. Hyht wæs geniwad.

Aras ţa togenes, gode ţancade

ţæs đe hie onsunde æfre moston

geseon under sunnan. Syb wæs gemæne

bam ţam gebrođrum, blis edniwe.

Then he saw his sweet companion under heaven, the holiest of the holy. Hope was renewed. They both raised themselves and thanked God that they could meet safe and sound under the sun. Peace was between them, as they were restored to happiness. (Andreas: 11. 1009-1014)

The poet depicts the relationship between Andreas and Matthew as a conceptual reversal of the community that the Mermedonians represent. He makes it manifest that their heathen community is unable to value kinship and lordship loyalties. At first, the Mermedonians are ironically described in heroic terms as "hæđne hild-frecan" 'fierce heathen warriors' (Andreas: 11. 1067-1071). The poet deliberately describes the Mermedonians as a comitatus of men who remain steadfastly loyal to one another.

\footnotetext{
Beornas comon,

wiggendra ţreat, wicgum gengan,

on mearum modige, mæđelhegende,

æscum dealle. ţa wæs eall geador

to ţam ţingstede ţeod gesamnod.
}

The warriors gathered, a horde of fighters riding on horses, conversing together, proud of their spears. All of them were gathered together in the meeting-place. (Andreas: 11. 1093-1112)

The inflated heroic idiom, however, quickly gives way to overt mock-heroic parody of the warrior ethics. The Mermedonians arrive at the prison to satisfy their hunger by consuming Matthew. On realising the fact the Mathew escaped from prison, they have no other alternative than to cast lots to choose one of their own number as the next prey to their cannibalistic practice. When they choose their chieftain, he suggests that his companions eat his own son instead of him. This episode, according to Shannon Godlove, constitutes "a parodic echo of John 3:16. The biblical passage explains that God gives his son as sacrifice out of his 
'love for the world"' (Godlove 2009: 152). ${ }^{23}$ Apart from being a parody of the Eucharist, the episode defies the heroic perception of the kinship obligation that burden individuals with the responsibility to protect their family. The chieftain who is chosen to be eaten gives away his son to save his life is described ironically as "collen-ferđ" (Andreas: 1. 1108).

Cleopode ţa collenferhđ cearegan reorde, cwæđ he his sylfes sunu syllan wolde on æhtgeweald, eaforan geongne, lifes to lisse.

The bold one said, with troubled voice, that he would give his own son as food, the young offspring, and go on to enjoy his life. (Andreas: 11. 1108-1110)

The incongruous placing of heroic elements humorously demonstrates that the Mermedonian community does not match the heroic ideal of masculinity. Although the Mermedonians possess strength and prowess, their community is not driven by the homosocial desire of the heroic kind. In contrast, Andreas and Matthew's performance of Christian charity is represented in both homosocial and heroic terms.

Andreas's passion is still conceptualised in quasi-heroic terms. For example, while the Andreas-poet supplies a positive evaluation of Andreas's spiritual heroism, he is maintaining his representation of the Mermedonians and the devils as an inverted comitatus, a parody of homosocial bonding (Andreas: $11.1095 \mathrm{ff}$.). When Andreas has been placed in prison, he is attacked by seven devils. Once they perceive the sign of the cross on his forehead, they defect, disregarding their leader's order to stay and fight loyally. One of the devils is making an excuse to his "father" (Andreas: 1. 1346).

Ne magan we him lungre lađ ætfæstan,

swilt ţurh searwe. Ga ţe sylfa to!

ţær ţu gegninga guđe findest,

frecne feohtan, gif đu furđur dearst

to ţam anhagan aldre geneđan.

We cannot wage warfare against him any longer. Go and fight alone if you immediately find an army to fight boldly if you dare risk your life combating the holy one. (Andreas: 11. 1347-1351)

The devil's cowardice is juxtaposed to Andreas's courage and his bond of loyalty to Matthew. ${ }^{24}$

23 Robert Boenig claims that the poet produces a theological parody of the Eucharist (1991: 73). Alexandra Bolintineanu objects his allegorical reading of the cannibalism, since the poet describe "the Mermedonians as lacking bread and water rather than lacking and wine... This change turns the absence of bread and water into a comment on the literal abnormality of the Mermedonians's diet" (2009: 152).

24 Jonathan Wilcox makes an extended comment on the mock-heroic potential of the encounter between Andreas and the devils (2003: 207-208). 
The tension between the values of comitatus and religious solitude also emerges at the end of the poem. Andreas's mission to convert the heathen Mermedonians is accomplished, the saint must continue his apostleship elsewhere. As the poet describes his departure, he portrays the emotional bond forged between him and the Mermedonians.

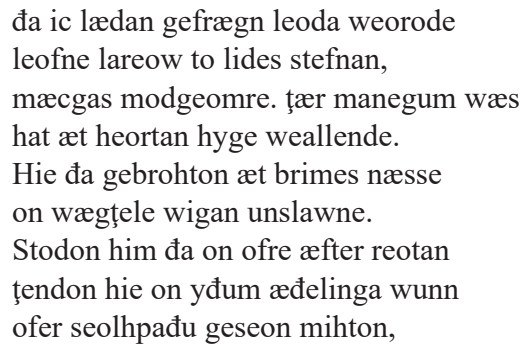

Then, I heard that the people led their beloved teacher to the ship and that hot emotion surged in the hearts of the sad companions. They brought him, the zealous warrior, to the ship at the promontory. They were standing around him and lamenting on the shore as they could see him, the joy of men, on the seal's path (the sea). (Andreas: 11. 1706-1714)

A Christian performs an ongoing conversion from the secular world. Amity Reading examined 'Andreas's use of its own unique 'incomplete' typological structures to present its saint as a model not of perfect sanctity, but of continuous, fallible conversion" (Reading 2015: 5). I would like to suggest that Andreas, as an outcast, is a model for the monastic idea of conversion from the secular world. The "others" that are constructed throughout the narrative are the residue of individual pre-conversion pasts that cannot be completely repressed. Andreas rejects the homosocial bond with the Christianised Mermedonians, because Christian identity is always constructed as an antithesis to community.

The theme that Andreas unfolds is that Christian identity is grounded on its essential otherness in relation to secular culture. Reinventing the parameters of masculinity that are registered in Old English religious poetry is profoundly subversive and the Andreas poet wrote so as to foster religious parameters of identity that remain outside the secular norms for representing men. The saint's body in Andreas defies the norms of the masculine body in that it fails to represent the values of the secular world. Consequently Andreas, the other apostles, and Christ himself are necessarily depicted as the abject, who live as outcasts, beyond heroic society. The poems depiction of non-conformative masculinity constructs them as exiles devoid of earthly treasure, as in Old English elegies, but as a societal other whose true home, if not in a monastery, is in heaven. 


\section{References}

Augustine. 1991. Confessions. Chadwick, H. (trans.). Oxford: Oxford University Press.

—. 2003. The City of God. Bettenson, H. (trans.). London: Penguin Books.

Baker, P.S. 2013. Honour, Exchange and Violence in Beowulf. Cambridge: D.S. Brewer.

Baselmans, J. 1999. By Weapons Made worthy: Lords, Retainers and Their Relationship in Beowulf. Amsterdam: Amsterdam University Press.

Biblia Sacra Vulgata. [1969] 2007. Weber R. and R. Gryson (eds.). $5^{\text {th }}$ ed. Stuttgart: Deutsche Bibelgesellschaft.

Biggs, F.M. 1988. “The Passion of Andreas: Andreas 1398-1491.” Studies in Philology 85:4. 413427.

Boenig, R. 1991. Saint and Hero: Andreas and the Medieval Doctrine. Lewisburg: Bucknell University Press.

Bolintineanu, A. 2009. "The Land of Mermedonia in the Old English Andreas." Neophilologus 93. $149-164$.

Brady, L. 2010. "Echoes of Britons on a Fenland Frotier in the Old English Andreas." The Review of English Studies 61:252. 669-689.

Brooks, K.R. (ed.). 1961. Andreas and the Fates of the Apostles. Oxford: Clarendon Press.

Cohen, J.J. 2003. Medieval Identity Machines. Minneapolis: University of Minnesota Press.

Christie, E. 2004. "Self-Mastery and Submission: Holiness and Masculinity in the Lives of AngloSaxon Martyr-Kings." In: Cullum, P.H. and K.J. Lewis (eds.). Holiness and Masculinity in the Middle Ages. Cardiff: University of Wales Press. 143-157.

Fee, Ch. 1995. "Productive Destruction: Torture, Text, and the Body in the Old English Andreas." Essays in Medieval Studies 11. 51-60.

Fulk, R.D, R.E. Bjork and J.D. Niles (eds.). 2008. Klaeber's Beowulf. $4^{\text {th }}$ ed. Toronto: University of Toronto Press.

Godlove, S.N. 2009. "Bodies as Borders: Cannibalism and Conversion in the Old English Andreas." Studies in Philology. 137-160.

—. 2015. "The Reluctant Apostle: Heroic Rhetoric and Human Frailty in the Old English Andreas." Medieval Perspectives 30. 181-205.

Greenfield, S. 1989. Hero and Exile: The Art of Old English Poetry. London-Ronceverte: Hambledon.

Hamilton, D. 1975. "Andreas and Beowulf: Placing the Hero." In: Nicholson, L.E. and D.W. Frese (eds.). Anglo-Saxon Poetry: Essays in Appreciation for John C. McGalliard. Notre DameLondon: University of Notre Dame Press. 81-98.

Hieatt, C.B. 1976. "The Harrowing of Mermedonia: Typological Patterns in the Old English Andreas." Neuphilologische Mitteilungen 77. 54-55.

Hill, T.D. 1969. "Figural Narrative in Andreas: The Conversion of the Mermedonians." Neuphilologische Mitteilungen 70. 261-273.

Hill, J. 1981. "The Soldier of Christ in Old English Prose and Poetry." Leeds Studies in English 12. $57-80$.

Hobbs, R. 1995. “The Language of Warfare and the New Testament.” In: Esler, Ph.F. (ed.). Modelling Early Christianity: Social-scientific studies of the New Testament in context. London-New York: Routledge. 248-262.

Irving, E.B. 1983. “A Reading of Andreas: The Poem as Poem.” Anglo-Saxon England 12. 215-237.

Keufler, M. 2001. The Manly Eunuch: Masculinity, Gender Ambiguity, and Christian Ideology in Late Antiquity. Chicago-London: The University of Chicago Press.

Klinck, A.L. 1992. The Old English Elegies: A Critical Edition and Genre Study. Montreal: McGillQueen's University Press.

Krapp, G.Ph. (ed.). 1931. The Junius Manuscript. New York: Columbia University Press. 
Lees, C.A. "Engendering Religious Desire: Sex, Knowledge, and Christian Identity in Anglo-Saxon England." Journal of Medieval and Early Modern Studies 27:1. 17-45.

McAvoy, L.H. 2011. Medieval Anchoritisms: Gender, Space and the Solitary Life. Cambridge: D.S. Brewer.

Morrison, S. 1979. "Of Cempa in Cynewulf's Juliana and the Figure of the Miles Christi." English Language Notes 17:2. 81-84.

Peters, L.J. 1951. "The Relationship of the Old English Andreas to Beowulf." PMLA 66. 844-863.

Reading, A. 2015. "Baptism, Conversion, and Selfhood in the Old English Andreas." Studies Philology 112:1. 1-23.

Roberts, J. 1979. The Guthlac Poems of the Exeter Book. Oxford: Clarendon Press.

Schaff, Ph. (ed.). Ambrose. Selected Works and Letters. https://www.ccel.org/ccel/schaff/npnf210. html.

—. Latin Christianity: Its Founder, Tertullian. http://www.ccel.org/ccel/schaff/anf03.html.

Shippey, T.A. 1971. Old English verse. London: Hutchinson University Library.

Schneider, C. 1978. "Cynewulf's Devaluation of Heroic Tradition in Juliana." Anglo-Saxon England 7. $107-118$.

Smith, K.A. 2011. War and the Making of Medieval Monastic Culture. Woodbridge: The Boydell Press.

Waugh, R. 2012. "The City as Speaker of the Old Testament in Andreas." In: Fox M. and M. Sharma. Old English Literature and the Old Testament. Toronto: Toronto University Press. 253-265.

Wilcox, J. 2003. "Eating People is Wrong: Funny Style in Andreas and its Analogues." In: Karkov, C.E. and G.H. Brown (eds.). Anglo-Saxon Styles. Albany: State University of New York Press. 201-222. 